Vol. 2, No. 2, July 2019, hlm. 231-236

ISSN 2614-1981 (Print)

ISSN 2615-0352 (Online)

Journal of Management and Business Aplication

\title{
THE INFLUENCE OF ROLE CONFLICT, STRESS AND WORK ENVIRONMENT ON PERFORMANCE OF TEACHERS
}

\author{
Sian Harsep Logitapraja ${ }^{1}$ \\ Imam Suroso \\ Hary Sulaksono ${ }^{3}$ \\ High School of Economics of Mandala \\ Email: xiantzlg@yahoo.co.id
}

\begin{abstract}
Employee performance is one of the benchmarks of success of an organization, whether it is good or not. So does that happen in school which is a company engaged in the field. For that, there is a need to research to find out what factors affected it. This research aims to find out if there is a conflict between the role of influence, stress, and work environment against performance of the teacher in SMK N IU Singojuruh, and became the object of this research that is all teachers teaching in SMK N IU Singojuruh Banyuwangi. Using Multiple regression analysis using SPSS software help. The results of this study demonstrate a significant influence between the role conflict, stress, and work environment against performance of the teacher in SMK N IU Singojuruh Banyuwangi simultaneously as well as partial in each from. In addition, in this study also noted that the working environment variable is the most dominant factor affecting performance.
\end{abstract}

Keywords: role conflict, work stress, work environment and the performance of teachers

\section{INTRODUCTION}

The school is one of the organizations that are engaged in the service of education. The existence of human beings in the organization known as employees or teachers is one of the strategic resources which have great participation in the process of teaching and learning in schools. A capability of teachers in educating students becomes a major concern in the process of educating students. At the core of human resources Management is a managerial efforts in blending and balancing between the needs of personnel, employees and management, with the objectives of the Organization

The value of performance cannot be released from the role of teacher and employee performance. Low employee performance, overall will affect the productivity of the company/school. (Anorogo, 2012:101). Naik-turunnya the performance of teachers and employees allegedly related to how the school is treating employees in a day-a day as "human" and not as a machine.

Based on these reasons, then the research will be focused on the performance 
of teachers. Because the teacher is the party directly dealing with consumer, as students at the school. While the employee or produce educators in this effort TU, not done research, so the researchers focused on an examination of the performance of teachers.

The phenomenon of the emergence of conflicts and stress among teachers can also be experienced in Ihya ' Ulumudin Singojuruh. This is apparent from the observations while on the productive teacher. Of the three existing Departments, whether it be majoring in accounting, Department of TKR or TKJ, there are no teachers who have the competencies that are linear with a diploma which is owned, allowing the onset of conflict of roles.

The role of prolonged conflict and without any definite settlement can trigger stress work. It can also be seen in the classes that are taught, lots of teachers who arrive late incoming class. It is also possible due to the work environment that is less conducive. Therefore, it may be interesting enough researched to know the influence of the role Conflict, Stress and work environment Against performance of the teacher in SMK N Ihya ' Ulumudin Singojuruh, Banyuwangi

Dharma (2008:30) stated that the performance was something done or products/services generated or granted a person or group of people. The sense of looking at the performance of the two sides, namely from the individual and the organization. On the basis of an opinion on performance measurement at the top, in the study of employee performance indicators that are used are: quantity, employment, quality of jobs, and timeliness. The quantity of work, i.e. the amount or the number of jobs generated employees. Types of work related to the field of production, the quantity of the right tools to measure the performance of employees. Therefore not all types of work can be measured by the quantity of the work (Syarief, 2007:74). The quality of the work, is one way to find out the employee's performance can be assessed tinggirendahnya of sejauhmana employees can complete his work with the kualits. According to Syarief (2007:76), the quality of the work consists of fineness, cleanliness and thoroughness of work. Timeliness, is one way to find out the tinggi-rendahnya performance of employees, on the basis of timeliness. High performance employees called in the employee complete the task quickly and accurately. Therefore further Dharma (2008:55) stated that timeliness can be seen from the completion of the work or not in accordance with the planned time

Definition conflict aplenty to be found. As a simple definition, conflict refers to each of the tension experienced by someone when he holds that needs or desires is impeded or discouraged (Hartono, 2010:2), the tension can arise because the person concerned undergoes a confusion. Or want two things that do not fit between the one with the other. Based on the opinion of Gibson, (2012:257), the main cause of the occurrence of pressure (stress) is a conflict of roles. The next Gibson (2012:258), divide the conflict into three forms of role conflict, among others: a private role Conflict). Private role conflict occurs when the requirements of the role of breaking the basic roles, attitudes and needs of the individual who holds the position. b) intra Conflict of roles. A conflict occurs when the individual roles of intra formulate a set of different expectations, so it is impossible for someone who plays a role can meet all expectations. It is more likely to occur if certain roles have a complex role device (many link different roles). c) conflicts between roles. Conflict between role can be produced from a wide variety of roles. This happens in the individual simultaneously as many do a lot of roles, and some of them have conflicting expectations.

According to Matteson and Ivancevich (2007:10), stress is the response of someone 
good in the form of emotions, the physical and cognitive (conceptual) against certain situations that prompt demands on the individual. From the sense can be expressed that there are three main components of the stress stimulus components, i.e. components of response and interaction components. Siagian (2012:148), stated that the stress will manifest itself in a variety of forms such as high blood pressure, irritability, hard to take the simplest decisions, loss of appetite, are likely to have an accident, and a variety of other forms. Various forms of stress can be classified in three categories, namely, physical, psychological, and organisatoris.

According to Sedarmayanti (2011:21) the working environment is a whole tool gadgets and materials at hand, the surrounding environment where a person works, the method works as well as setting it works either as an individual or group. According to the work environment indicators Nitisemito (2012:159) is as follows: a) the atmosphere of the work. The specified working conditions are pleasant, comfortable and safe for every employee who was in it. Each employee has always wanted a fun work atmosphere, comfortable and safe, because with such a work atmosphere that makes employees more zeal in carrying out his job. b) relationships with co-workers. Relationship in question in this case is the relationship with colleagues in harmony and without any mutual intrigues among fellow co-workers. One of the factors that affect the employees remain in one organization is existence of a harmonious relationship and kinship is one of the factors that can affect the performance of the employee. c) the availability of on-site work. Facilities work in question here is the equipment used to support the smooth running of the work. Availability of the full work facilities, although not new is one of supporting the process of smoothness in the works
Based on a review of literature on top, then formulated the following hypothesis: there are significant influence between the role Conflict, stress and work environment Against performance of the teacher in SMK N Ihya ' Ulumudin Singojuruh Banyuwangi Regency.

\section{RESEARCH METHODS}

Based on the background issues and the formulation of the problem that there are characteristics of the problem examined in this research can be classified as explanatory research or confirmatory research i.e. research that explains the causal relationships and test the link between multiple variables through hypothesis testing or research description (Singarimbun and Efendi, 2009:256)

Role conflict scale was compiled based on indicators including: personal role conflict, conflict, and conflict intraperan antarperan. Work stress scale was compiled based on indicators including: physical stress, psychological stress, and stress organisatoris. And the scale of the work environment was drawn up on the basis of indicators, namely: the atmosphere of work, relations with colleagues and the availability of facilities. While the scale of performance drawn up on the basis of indicators, namely: the quantity of work, quality of work, and timeliness.

The analysis of data used to process data of the research is to use the approach to statistics ". Hypothesis testing in this study using multiple regression analysis to test using the progam SPSS (Statistical Package for Social Science).

\section{RESULTS ANALYSIS}

Computer calculation results shows that the value of Fhitung to the level of significance of 0.0035 .126 . Where is their significance level smaller than 0.05 ; so based 
on this data it can be concluded that free variables are jointly significantly to influential variables are bound. This is in accordance with the first hypothesis in ask, so that the first hypothesis is accepted.

While the results of the calculation of the statistics show that variable conflict role with the level of significance of 0.050 .002 variable $<0.05$ and variable work $<$ work stress with significant levels of $0.004 \quad 0.05$. This means $<$ environments with significant levels of 0.004 partially variable role conflict, stress and work environment have a significant influence on performance teacher IU Singojuruh (Y1). Thus the hypothesis put forward by the results obtained show the correct results. In other words Ha Ho accepted and rejected.

\section{INTERPRETATION}

Regression analysis of the obtained results that influential role conflict against the variable performance of the teacher in SMK N IU Singojuruh with koefesien regression of 0.254 with negative sign on the results of the data processing. That is, it can be said that the higher role conflict, then the variable performance of the teacher in SMK N IU Singojuruh is getting low. Vice versa, the lower the role conflict, then the variable performance of the teacher in SMK N IU Singojuruh higher. Work stress variables with koefesien regression of 0.335 with negative sign on the results of the data processing. That is, the higher the stress of work, then the performance of the Teacher is getting low. Vice versa, the lower work stress, then the higher Teacher performance. While the working environment results in variable data processing with the koefesien regression of 0.475. Based on the above explanation, then it can be said that the higher the working environment variable then the higher performance of the teacher in SMK N IU Singojuruh. Vice versa, the lower the work environment variable then the lower the performance teacher at SMK $\mathrm{N}$ IU Singojuruh. This is in accordance with the theories expressed by Nitisemito (2012:159) stating that an atmosphere of work, relationship with colleagues, as well as the availability of on-site work participated in supporting the smooth process in the work so that the employee's performance increases. The research was also supported by the presence of research conducted by Subechi (2015:73) that there is a positive and significant influence of work environment on performance. And the working environment is the most dominant factor affecting performance.

The variables contained in the research such as the conflict of roles $\left(\mathrm{X}_{1}\right)$ has an effect on the performance of teachers. In order for the conflict which occurred in the role of teachers can be pressed into existence, hence the need for the construction of the party's leadership in this Principal to the teachers on an ongoing basis, so that the role of the conflict can be resolved. In addition, work stress $\left(\mathrm{X}_{2}\right)$, which can be reduced with often do training and training-training followed by teachers of subjects, at the training institutions that have been working with the school so that teachers ' performance. As for the working environment variables $\left(\mathrm{X}_{3}\right)$, needs to be enhanced by the school by assigning wakasek the field of infrastructure to complement the facilities less and improve the facilities has not been feasible so that the atmosphere of the comfortable classes so that teachers ' performance increased.

\section{CONCLUSION}

Based on the results of the analysis and discussion on the previous chapter, then the conclusions can be presented from this study are: (1) the third free variables take effect simultaneously (synchronously) against the performance of the teacher in SMK N IU 
Singojuruh Banyuwangi. (2) The third free variables turns out to be partially significant effect against the performance of the teacher in SMK N IU Singojuruh Banyuwangi. As for the third variable non researched proven that free variables (x 1) role conflict, work stress (X 2), and the work environment (X 3) influence of $25.4 \% ; 33.5 \%$; and $47.5 \%$ against the performance of the teacher in SMK N IU Singojuruh Banyuwangi. (3) Of these three variables which have a dominant influence on performance — teacher IU Singojuruh Banyuwangi is a work environment that is amounting to $47.5 \%$.

\section{REFERENCES}

Anorogo, P. dan N. Widyawati, 2012, Psikologi dalam Perusahaan, PT. Rineka Cipta Jakarta

As'ad, Moh., 2011, Seri Ilmu Sumber Daya Manusia Psikologi Industri, Cetakan Keenam, Liberty, Yogyakarta

Darman, Triono. 2001. Analisis Pengaruh Konflik dan Stres pada Kinerja Karyawan Pabrik Pengolahan Kertas dan Stationary PT Pantja Niaga Di Surabaya. Tesis. Jember: Universitas Jember.

Dharma, A. 2008. Gaya Kepemimpinan yang Efektif bagi Manager. CV. Sinar Baru Bandung.

Gibson, James L John.2012. Manajemen: Organisasi Perilaku Struktur Proses. edisi ke 5. Erlangga. Jakarta.

Gitosudarmo, I dan I Nyoman Sudita, 2007, Perilaku Keorganisasian, BPFE, Yoyakarta.

Hadi, S, 2010. Metode Research, Jilid Satu, Yayasan Penerbit Fakultas Psikologi Universitas Gajah Mada Yogyakarta.

Hartono, T. 2010. Manajemen Konflik : Short Couse dan Workshop Kepemimpinan Tingkat Nasional IX, Senat Mahasiswa FIA Unibraw. Malang.
Heidjrahman, dan S Husnan, 2013, Manajemen Personalia, Edisi IV, BPFE, UGM. Yogyakarta.

Iqbal, Muhammad. 2016. Pengaruh Konflik Peran Ganda dan Stres Kerja Terhadap Kinerja Pegawai Wanita Pada Rumah Sakit Umum Daerah Menggala. Tesis. Lampung: Universitas Lampung

Ivancevich, J.M., dan M.T. Mettenson. 2007. Stress dan Work, Gelnview; Scoth, Foresman and Company

Maulana M, Subechi. 2015. Pengaruh Konflik dan Lingkungan Kerja Terhadap Kinerja Karyawan. Skripsi. Semarang. Universitas Negeri Semarang

Nitisemito, Alex S, 2012. Manajemen Personalia: Manajemen Sumber Daya Manusia. Ghalia Indonesi, Jakarta.

Nunnally, 2000. Using Mutivariate Statistics, third edition, Harper Collin. New York

Saydam, G. 2010. Manajemen Sumber Daya Manusia (Human Resource Management). Djambatan, Jakarta.

Santoso, Singgih. 2002. Buku Latihan SPSS Statistik Parametrik. Cetakan ke-1. Jakarta: PT Elex Media Computindo.

Sedarmayanti.2011. Sumber Daya Manusia dan Produktivitas Kerja. Mandar Maju, Bandung.

Syarif, R. 2007. Teknik Manajemen Latihan dan Pengembangan. Angkasa. Bandung.

Siagian, SP. 2012. Teori Organisasi, Bumi Aksara, Jakarta.

Singarimbun, M. dan S. Efendi, 2009, Metode Penelitian Survey, LP3ES, Jakarta.

Sudjana. 2006, Teknik Analisis Regresi dan Korelasi, bagi Para Peneliti, Edisi Ketiga Tarsito. Bandung.

Sugiyono, 2016. Metode Penelitian Kuantitatif, Kualitatif, dan $R \& D, C V$. Alfabeta, Bandung.Cetakan ke-24

Swasto, BS. 2009, Pengembangan Sumberdaya Manusia, Pengaruhnya 
terhadap Kinerja dan Imbalan, Penerbit FIA, Unibraw. Malang.

Tamauka Marsello Giovanni, dkk. 2015. Pengaruh Konflik Peran, Konflik Kerja dan Stres Kerja Terhadap Kinerja Karyawan Pada PT Air Manado. Jurnal EMBA.Vol.3, No.3 Sept.2015,Hal. 90-98

Umar, H. 2003. Riset Sumber Daya Manusia Dalam Organisasi. PT. Gramedia Pustaka Utama Jakarta.
Winardi, 2012, Manajemen Perilaku Organisasi, PT. Citra Aditya Bakti, Bandung

Yebbi Hardilabogi, Sampeadi. 2015. Pengaruh Konflik dan Stres Kerja Terhadap Kinerja Melalui Semangat Kerja Pada Karyawan Tetap PT FIF Group Cabang Lumajang. Artikel Ilmiah Mahasiswa. Jember. Universitas Jember. 